\title{
EXPERIMENTAL ESTIMATE OF THE HEAT FLOW PARAMETERS OF HEATING APPLIANCES
}

\author{
Viktor Pukhkal* \\ Faculty of Engineering Ecology and Municipal Facilities, St. Petersburg State University of \\ Architecture and Civil Engineering, St. Petersburg, Russia
}

The knowledge of radiant and convective heat flows distribution from heating appliances is required for a development of an efficient heating systemsmaintainingnecessaryconditions in rooms at the lowest energy requirements. The study method is developed and provided. The heating appliances of water heating system (convection heater and radiator) are studied. The results of heating appliances heat flow measurements are given. Radiant and convective components of heating appliances heat flow are determined.

Key words: Heating, Heating appliance, Radiant heat flow, Convective heat flow

\section{INTRODUCTION}

Optimization of the heating system is an important component of complex of measures, directed at reducing energy consumption in new and renovated buildings $[01,02,04,06,07,10]$.

Heating appliances are divided into three groups by prevalent type of heat emission $[03,08]$ :

- convective - emitting by convection no less than $75 \%$ of total heat flow;

- convective-radiant - emitting by convection between 50 and $75 \%$ of total heat flow;

- radiant - emitting by radiation no less than $50 \%$ of total heat flow.

Heating appliances heat flow is determined by an experiment without separation of radiation and convection heat components [09, 11, 12]. Main factors determining heat flow values are the type and the design of the appliance, and the temperature lift - the difference between average heat carrier temperature and surrounding air temperature for the appliance.

The estimation and analysis of heated rooms microclimate and the efficiency of heating energy requirements would be possible only if convective and radiant heating appliances heat flows are determined by an experiment.

\section{PROBLEM STATEMENT}

The experimental estimation of the heat flow and its convective and radiant components is performed for two types of heating appliances:

- „Atoll“-type convection heater (PKN 310) manufactured by „Isoterm OJSC“ (Russia) (Figure 1);

- „Profil-Kompakt"-type panel radiator (FKO 22-03-09) manufactured by „Kermi“ (Germany) (Figure 2).

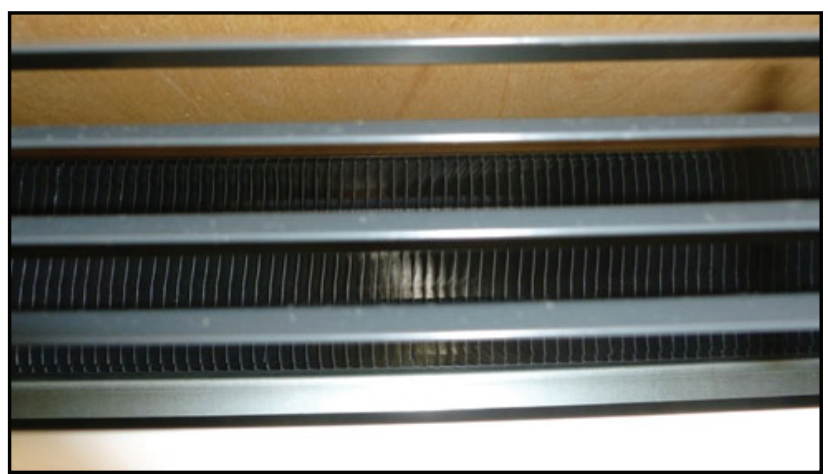

Figure 1: Wall convection heater „Atoll Pro“ 
The basic model of „Atoll“ convection heater is designed wall-mouted and end-capped with side connections and is shown on the Figure 1 . The frontal panel is convex-shaped.

Heating convector's heating unit is made of copper pipes of $15 \mathrm{~mm}$ outer diameter and $0.4 \mathrm{~mm}$ thickness, and aluminum plates of $0.22 \mathrm{~mm}$ thickness profiled by horizontal and vertical swages. The plates are set on the pipes. The height of the plates is $100 \mathrm{~mm}$. The plates fin step is $6 \mathrm{~mm}$. There are 2 horizontal tubes in the plates for each $50 \mathrm{~mm}$ in height. The fin thermal contact with pipes is ensured by mandrelling of the pipes by $0.5 \mathrm{~mm}$. The panel radiator consists of two rows of convective finning with $100 \mathrm{~mm}$ in depth and $300 \mathrm{~mm}$ in height located between the plates and welded to each panel. The U-shaped vertical finning is made of steel of $0.5 \mathrm{~mm}$ thickness and is spot welded to panels from backside directly onto walls of vertical heat carrier ducts. This design increases heat pickup from the panels mostly by convection.

The radiator is designed by „X2“ technology (Figure 2). The technology is based on sequential heat carrier binding: the heat carrier from the supply pipe first enters the front panel; the back panel functions as the reflective barrier. In that case heat losses are decreased because of the emission on cladding surface behind the radiator.

a) general view
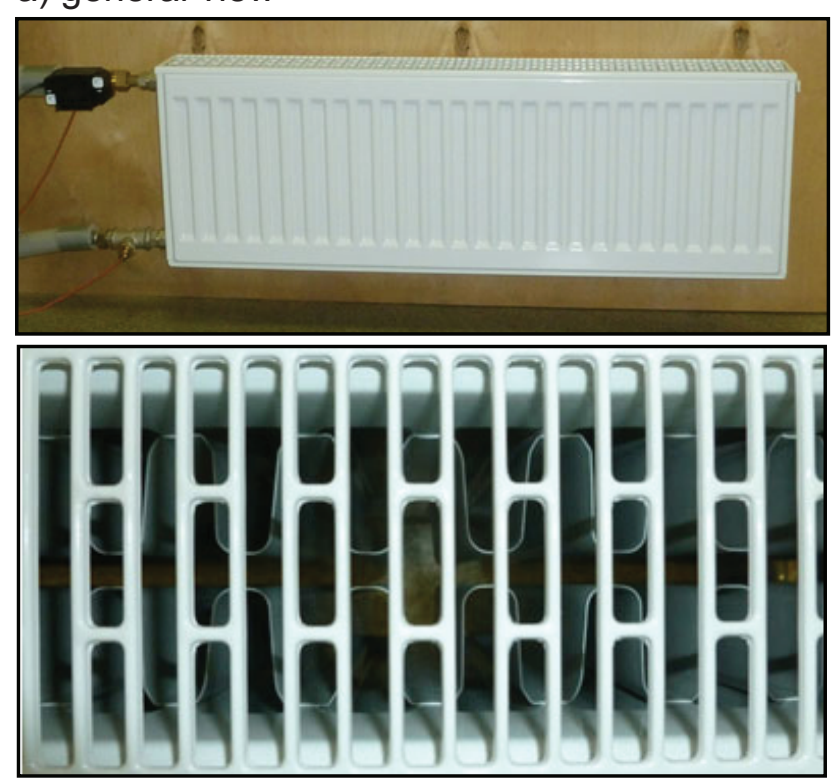

b) heat carrier movement diagram [12]

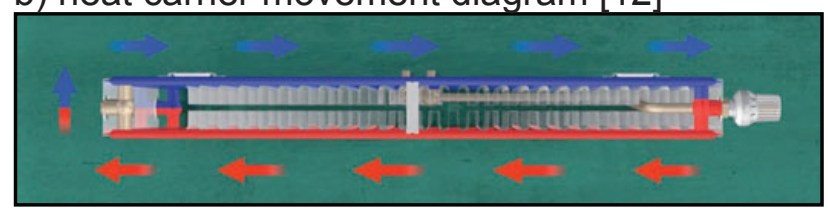

Figure 2: „Profil-Kompakt"-type radiator (FKO 22) by „Kermi"

\section{METHOD}

To determine heating appliances heat flow we used an experimental apparatus measuring following parameters:

- Heat carrier's temperature at heating appliance entrance, exit and room air temperature - by platinum thermometers Pt500 which are part of "Multical 602" heat meter;

- Heat carrier's flow-by an ultrasound flowmeter from „Multical 602“ heat meater;

- Heating appliance surface temperature-by surface thermometer Testo 905-T2 and the infrared imager (ThermaCAM E45 camera manufactured by „FLIR“ and ThermaCAM QuickView software package for report preparing).

Heating appliance surface temperature was measured by surface thermometer Testo 905-T2 only in static conditions as fixed points for infrared imager measures control. It was necessary due to inertia in surface type instruments.

The cladding structure's temperature was not controlled. Before each experiment (before turning the heater on) the room's thermal background image was shot.

Total heating appliance's heat flow was determined by heat meater data:

$Q=G \cdot c \cdot\left(t_{1}-t_{2}\right), \mathrm{W}$,

where:

$G$ - mass heat carrier flow rate, $\mathrm{kg} / \mathrm{s}$;

$c$ - heat carrier specific heat per unit mass, $\mathrm{J} /\left(\mathrm{kg} \cdot{ }^{\circ} \mathrm{C}\right)$;

$t_{1}$ - heat carrier temperature at appliance entrance, ${ }^{\circ} \mathrm{C}$;

$t_{2}$ - heat carrier temperature at appliance exit, ${ }^{\circ} \mathrm{C}$.

Radiant heat flow from heating appliance's heated surface to internal cladding surfaces [5].

$Q_{r}=\varepsilon \cdot C \cdot \varphi \cdot F \cdot\left[\left(\frac{t_{m s}+273}{100}\right)^{4}-\left(\frac{t_{s, r}+273}{100}\right)^{4}\right], W /\left(m^{2.0} \mathrm{C}\right)$,

where:

$E$ - emissivity factor of mutually irradiating bodies; $E=0.9$ for convection heater casing surface; $C$ - radiation coefficient of black body; $\mathrm{W} /\left(\mathrm{m}^{20} \mathrm{C} 4\right)$; $\varphi$ - irradiancy coefficient demonstrating which part of black body emitted energy reaches heating appliance's cladding casing; for heating appliances $\varphi=1$; 
$F$ - heating appliance heat-releasing surface area, $\mathrm{m}^{2}$

$t_{m . s}$ - heating appliance heat-releasing surface average temperature, ${ }^{\circ} \mathrm{C}$;

$t_{s, r}$ - irradiatedsurfaceaveragetemperature, ${ }^{\circ} \mathrm{C}$; for under the window mount of heating appliance it is assumed as internal air temperature, ${ }^{\circ} \mathrm{C}$. Convective heat flow from heating appliance:

$Q_{c}=Q-Q_{r}, \mathrm{~W}$,

where:

$Q_{r}$ - radiant heat flow from heating appliance's front panel and side surfaces (radiant heat flow from top and bottom surfaces can be ignored due to its insignificance), W;

$Q_{c}$ - convective heat flow, $\mathrm{W}$.

\section{ANALYSIS AND DISCUSSION OF THE RESULTS}

The heating appliances are tested in conditions commonly accepted for tests in Russia [11, 12].Radiant heating flow is calculated by mean values of each surface temperature: front, side and back. The examples of thermal images are shown on Figure 3.

a) convection heater

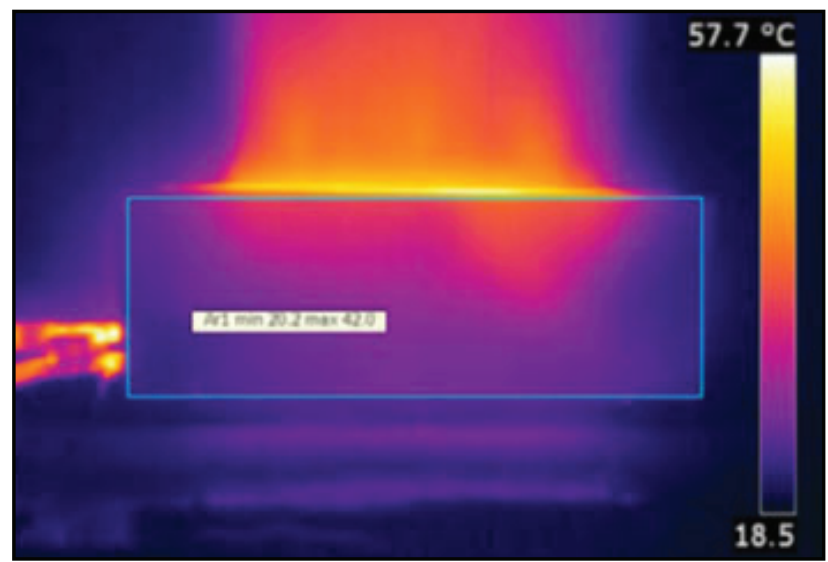

b) radiator

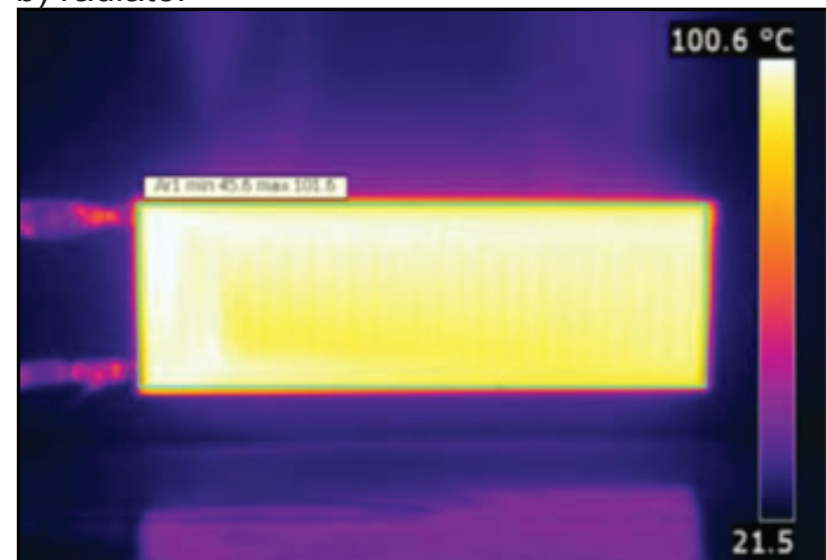

Figure 3: Heat appliance front panel's thermal imagesunder testing
The convection heater testing has determined that radiant part of total heat flow is $4 \%$ and convective part is $96 \%$, respectively. Thus, convective heat flow is a primal component and is generated by heating air between ribbed heating elements in the convective column formed by the heating unit and the front panel and the wall. For the radiator radiant part of total heat flow is $27 \%$, convective part is $73 \%$. The convective heat flow is a primal component in total heat flow and by prevalent heat emission type the radiator is approaching convective appliances.

For the radiator's back panel radiant part of total heat flow is $12 \%$. The radiator efficiency can be improved if the radiator's back panel radiant heat flow, which falls on the external wall, will be decreased.

\section{CONCLUSION}

1. The method for experimental estimation of radiant and convective heat appliances heat flows is developed.

2. The experimental estimation of radiant and convective heat flows is performed:

- For „Atoll“-type (PKN 310) convection heater manufactured by "Isoterm OJSC“ (Russia): radiant part of total heat flow is $4 \%$ and convective part is $96 \%$;

- For „Profil-Kompakt"-type (FKO 22-03-09) panel radiator manufactured by „Kermi“ (Germany): radiant part of total heat flow is $27 \%$, convective part is $73 \%$.

\section{REFERENCES}

1) Cvetkovska, M., Andreev, A., Trpevski, S., Knezevic, (2013), Parametric analysis of the energy demand in buildings with Passive House Standard, Conference, Portugal SB13 Contribution of sustainable building to meet EU 20-20-20, pp. 303-311

2) Cvetkovska, M., Knezevic, M., Rogac, M., (2012), Thermal insulation effects on energy efficiency of building structures, Civil and Environmental Engineering UGM, No. XXI/2, Vol. 5, pp. 1209-1215.

3) Krupnov B.A., Krupnov D.B. (2010): Heating appliances manufactured in Russia and CIS countries, Moscow: ASV Publishing House

4) Lazarevska, M., Trombeva-Gavriloska, A., Knezevic, M., Samardzioska, T., Cvetkovska, M., (2012): Neural network prognos- 
tic model for RC beams strengthened with CFRP strips, Journal of Applied Engineering Science, № 1 (10), pp. 27-30.

5) Mikheev M.A., Mikheeva I.M. (2010): Basics of heat transfer, BASTET Publishing House, Russia

6) Murgul, V., (2012) Povysheniye energoeffektivnosti rekonstruiruyemykh zhilykh zdaniy istoricheskoy zastroyki Sankt-Peterburga, Arkhitekton: izvestiya vuzov, № 4 (40) pp. 54-62

7) Samardzioska, T., Trombeva-Gavriloska, A., Cvetanovski, P., Popovski, D., Partikov, M., (2012): Strengthening and overbuilding of car service "Automakedonija» in Skopje, Makedonija, Journal of Applied Engineering Science, № 1 (10), pp. 53-58.
8) Skanavi A.N., Makhov L.M. (2008): Heating, Moscow: ASV Publishing House

9) Tiator I. (2006): Heating systems, Moscow: Tekhnosfera

10) Vatin, N., Nemova, D., Rymkevich, P., Gorshkov, A., (2012), Vliyaniye urovnya teplovoy zashchity ograzhdayushchikh konstruktsiy na velichinu poter teplovoy energii v zdanii, Inzhenerno-stroitelnyy zhurnal. № 8 (34). pp. 4-14.

11) Vitaterm LLC (2007): Reference manual for "Atoll“, „Atoll Pro“, and „Rodos“ convection heaters, Moscow

12) Vitaterm LLC (2013): Reference manual for „Kermi Therm X2" steel panel radiators, Moscow

Paper sent to revision: 07.02.2014.

Paper ready for publication: 15.03.2014. 